\title{
Improving the Performance of Pupils in Reading Using Word and Sentence Cards among Basic Four Pupils at Abuakwa R/C Primary, Eastern Region
}

\author{
${ }^{1}$ Prince Obeng-Himah, ${ }^{2}$ Doris Owusu Agyemang, ${ }^{3}$ Kwadwo Kombate, ${ }^{4}$ Nti Dominic \\ ${ }^{1}$ Department of Languages, Atebubu College of Education, Atebubu-Ghana \\ ${ }^{2}$ English Department, Prempeh College, Kumasi-Ghana \\ ${ }^{3}$ Department of Languages, St. Joseph's College of Education, Bechem-Ghana \\ ${ }^{4}$ Department of Languages, Berekum College of Education, Berekum-Ghana
}

\begin{abstract}
The purpose of the study was to determine the extent to which the pupils at the Abuakwa R/C Primary School can improve upon their reading ability. It was also to find out whether they developed the interest in studying of the English Language. The target sample of the study was made up of forty - nine (49) pupils that made up a whole class. Also, the target sample of the study was post - test, observation and interview as instruments to collect data. The pre-test was conducted before the intervention to reveal the problem while post-test was administered after the intervention to find out the effectiveness of the intervention. The data was collected following a weekly planned research activity. It was collected for the tabulated and converted into sample percentages. This was used for the analysis and discussions of the research question. In conclusion, the effectiveness of the intervention has really helped to improve upon pupils reading ability.
\end{abstract}

Keywords: Observation, Interview, Intervention, Interest, Improve.

\section{Introduction}

Reading has assumed greater significance today than ever before. The ability to read is essential to the individuals' growth in the modern world, to the capacity to benefit from the learning opportunities at school and beyond, and to the ability to take the important positions in society (Robertson, 1991)

The reading of books broadens the Childs vocabulary, language skills acquisition and hence the ability to think, comprehend and communicate with others. Also, books are to be valued for their power to bring fantasy and magic to children; for their positive influence on children's social, emotional and intellectual development; and for the understanding they can bring of the world and its people (Zwarestein ,1986). According to Fader (1966) the poorest man in the world is the man limited to his own experience, the man who does not read (Butler 1982).

According to Mellon (1990) the task of bringing the excitement and comfort, exploration and challenges of books to young people is a great joy. Understanding what students choose to read helps library and media specialists to build effective collections and develop reading ladders to broaden readers' tastes based on the materials they naturally enjoy.in this time of increased lifespan. It is important to nurture and encourage a lifelong enjoyment of reading. Ngendane (1989) states that reading increases the pleasure of leisure time. He goes on to state that the value of books and libraries is in laying a foundation for the development of intelligent and mature adults.

Libraries are a powerful weapon in the struggle against ignorance, poverty and tyranny (Ngendane, 1989). They provide information and also encourage reading for pleasure. Once pupils have developed the habit of reading for pleasure they feel comfortable reading for research or other purposes. Like Ngendane, Stripling (1985) also feels that reading for pleasure enables students to think and read at a higher level. They should be able to discover the main idea and subtleties of meaning; detect biases and points of view: evaluate the 
content and style of written material; and understand complex and controversial issues. Students should try to perfect their reading skills as this will help them to enjoy their reading.

The major psychological and developmental reasons behind encouraging children to read can be summed up by a passage from the introduction to Margaret Meek's 'The Cool Web' (1979). The worry that surrounds illiterates focus on the fact that they become social cripples, as that aspect of their lack is easy to define, but they are also shut out from a way of looking at the world which other people habitually use as if it were an extension of their perception. Unable to read, a child or adult is cut off from a way of entering into the experiences of other people, which would help him understand himself and other people better" (Thorpe, 1988). Probably, the greatest single reason for reading a book is exciting. The reader who interacts honestly and with perception when he/she reads, derives pure pleasure. It is then realized that reading is a deeply satisfying experience.

The benefits of reading are not instantly apparent and it is only through perseverance and the sampling of many types of books that the reader fees he/she is gaining something. A book can satisfy different psychological needs at different stages of our lives (Fricke, 1977).

Good books they say can show you your values thus, they can illuminate life choices. According to Jim Trealease, author of the Read-Loud-Handbook (in Hunt and Hampton, 1992) next to being hugged, reading aloud is probably the longest lasting experience in childhood. Reading aloud together is important for the same reasons that talking together is equally important: communication, sharing, bonding, inspiration, guidance, education and understanding. When people read together, they give each other a piece of their mind and a piece of their time, and that says a good deal about human worth. This habit gives the younger ones a common cultural heritage as well as a bond of sharing. Sharing books makes a good companionship: it opens up a whole new world for those who enters it.

Since the ability to read and comprehend is vital to an individual's achievement and development in life, soliciting the foundation at the formative years could not be over looked. At the Abuakwa R/C Primary School (Basic 4), reading as a whole is a serious problem. Even though there have been structures put in place to improve upon the reading skills of pupils, they still find it difficult to comprehend what they actually read. Also in the worst scenario, some pupils do not know how to read at all.

This study therefore sought to find out the problem that hindered reading in the school, and also to arouse the interest in reading at the primary school level since it is one of the most important skills pupils can learn at school. If they do not learn to read well, the rest of their education will be impaired (Thompson ,1979).

\section{Statement of the Problem}

Between the years 2010-2016, there have been persistent falling standards in education with respect to reading at Abuakwa R/C Primary School. In my research, there was an observation where pupils of the same age group vary in their reading habits hence it gave rise to the question of what causes the variation in reading habits. The question at the basis of this work is why some pupils who have the ability to read shy away from it. Better still, it presents the hope of whether or not reading habits can be improved or changed.

Pupils inability to read and comprehend what they read has become a great problem to the school and the district as a whole. For instance, in the researchers English lessons in the school, the researcher observed that, most pupils could neither read nor understand simple instructions given them in English so as a matter of fact, they always do things in ways that are not carefully planned or organized. In view of this, the researcher want to find out how 'Word cards and Sentence Cards' be used to improve the reading ability of the pupils in Abuakwa R/C Primary four.

\section{Purpose of the Study}

The study here aims at improving reading abilities of pupils at the Abuakwa R/C Primary School Class four (4). Fluency in the English language is vital so far as reading is concerned and this will be done by means of literature study as well as an empirical findings of the pupils in Abuakwa R/C Primary School (class 4). It is essential to note that, better reading habits can lead to better academic performance. 
In the literature study, attention will be given to the phenomenon of reading as well as the factors that may happen to influence it, nevertheless it is important to comprehend the reading phenomenon and the reading process as it will help the pupil to get a clearer perspective of it.

Also, this is aimed at proposing some guidelines and recommendations to guardians as well as parents and teachers in order to assist these pupils improve and inculcate healthy reading ability amongst pupils in the East Akyem municipality especially among the pupils of Abuakwa R/C Primary School (class 4).

\section{Research Questions}

To what extent can word cards and sentence cards be used to improve reading ability of basic four pupils of Abuakwa R/C Primary School?

\section{Methodology}

Action research used was a so as to get detailed information. The researchers employed this design to help understand what actually goes on in teaching and learning reading in a classroom situation.

Again, action research helped provide education on effective teaching since the teacher would be equipped to understand the various methods or approaches that best suit the pupils. The design was also a means of injecting new ideas into teaching and learning of reading. It is also a means of in-service training with new skills and methods of teaching reading. The population of pupils in the Abuakwa R/C Primary School (class 4 ) is four hundred and fifty (450) but the sample of the study was the basic four pupils which consisted of forty-nine (49) pupils. Out of these forty-nine (49) pupils, twenty-seven (27) were boys and twenty-two (22) were girls. Purposive sampling technique was used to select ten (10) pupils consisting of five (5) boys and five (5) girls in the class who are noted to have the most reading difficulty.

Teacher-made test was used for the pre-test data collection. This test consists of ten set of words selected from the pupils English course book. These were written on flash cards and the pupils were asked to pronounce them. Each correct pronunciation was scored two marks and a wrong pronunciation was scored zero. After administration of the pre-test, intervention activities were put in place using their word and sentence cards, syllabic and phonic methods of teaching reading. These were used as the methodology to help pupils overcome their reading difficulties thereby making reading enjoyable for them. Under this instrument that is test, it really reviewed the problem of reading because they couldn't read the passage given to them; this helped the researcher to adopt good intervention to solve this problem.

\section{Pre-Intervention}

The researchers realized the difficulties in reading of the pupils throughout the study at Abuakwa R/C primary school (class 4). In order to come out with an intervention to address the problem at stake, a procedure was adopted in trying to define the identified problem. A project was carried out using series of tests to identify their problem in reading. Finally, the researchers were able to identify the problem by giving pupils those tests.

\section{Intervention}

Various strategies were put in place in order to solve the problem of reading among pupils. Firstly, encouraging the use of more textbooks at the Abuakwa R/C primary school (class 4) was prescribed. The school did not have enough reading textbooks which made reading very difficult for the pupils. Due to this problem, the teacher always found it challenging teaching English reading. Pupils had to be paired into groups which made it difficult for them to comprehend due to the fact that, when lessons were in session, most of the pupils paid less attention. Obviously, it was not practically possible for ten (10) pupils to share one book.

The researcher also chose the syllabic and phonic method and word cards as the appropriate reading activities to be used to teach reading. She pronounced the words on the cards and the pupils were asked to repeat after her as she used the word cards. The pupils were then taken through the syllabic and phonic methods of pronunciations where the words were divided into syllables and pronounced as such.

The words used were selected from the pupils' course book. Examples of words used in teaching the concept are as follows: 


\begin{tabular}{|ccc|}
\hline Words & Syllabic & Phonic \\
\hline bamboo & bam-boo & boem bui \\
\hline farmer & far-mer & fa.r.me \\
\hline electricity & elec-tri-city & il.ek'tris.i.ti \\
\hline yesterday & yes-ter-day & jes.td.dei \\
\hline doctor & doc-tor & dak.ter \\
\hline & & \\
\hline
\end{tabular}

\section{Word cards}

A word card is a square or rectangular shaped card with words written boldly on it. Anytime there was a reading lesson, the researcher wrote the key words in the passage on a word card and led pupils through continuous drill on vocabulary items for correct pronunciation.

For example:
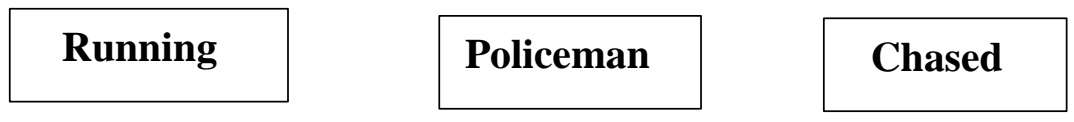

\section{Footsteps}

The researchers pronounced words on the word cards and showed the cards to the pupils to say after them. After that, individuals were called upon to pronounce the words. Throughout the exercise, the researcher encouraged the pupils who made good effort by saying "hat is a very good attempt." "You can do better."

The use of word cards for a good number of time helped pupils to memorize the vocabulary items they had learnt and they were able to pronounce the words whenever they came across them in the course of reading.

\section{Sentence cards}

A sentence card is almost like the word cards but with this, the vocabulary is used to form sentences to produce the meaning to pupils.

The sentence cards were introduced after the word cards. The meaning of the vocabulary was taught by using them to form sentences to introduce their meaning to pupils.

For example:

The boy is running to school

The policeman chased the thief

Apart from using sentences to introduce meanings of vocabulary items found in a passage to pupils, the researchers also drilled pupils with short and less difficult sentences that related to pupils interest. Here, pupils memorized the entire sentence. This method helped to train pupils to read from left to right and most importantly to read for meaning because the words are seen and heard in familiar contexts. For example, in the beginning, short sentences like "Philip can run" then 'Philip can run quickly', followed. Simple stories of four to six lines embodying some incidents were introduced.

The researcher also used reinforcement by giving positive comments and encouragement to pupils wherever reading tests were conducted and comprehension exercises were given and pupils with reading difficulties did well. The researcher praised pupils by writing remarks like good, excellent, keep it up, back up etc. against the marks scored in their books to motivate them to do well and participate in class activities next time. The researcher did this for a number of times in order to help pupils with reading difficulties to have interest in reading and also improve their academic performance.

\section{Post-Intervention}


After the intervention stage, out of ten pupils sampled, seven (7) pupils could read correctly whilst three (3) pupils were on the path to perfection. That is to say, pupils were given the same reading again and with the help of the techniques used the pupils impressive this time. This shows how effective the intervention techniques had been used.

\section{Data Analysis Plan}

The data collected was organized or put into tables. Meanwhile, the results were analyzed by using percentages. These techniques were used by the researcher because it was very simple and easy to understand, analyze and draw conclusions from it.

\section{Results/Discussion}

Research Question: To what extent can word cards and sentence cards be used to improve reading ability of basic four pupils?

\section{Table 1: Results and finding of the Pre-test and Post test}

\begin{tabular}{|c|c|c|c|c|c|}
\hline Pre-test & & & & Post test & \\
\hline Scores & $\begin{array}{l}\text { No. of } \\
\text { Pupils }\end{array}$ & $\%$ & Scores & $\begin{array}{l}\text { No. of } \\
\text { Pupils }\end{array}$ & $\%$ \\
\hline 1 & - & - & 1 & - & - \\
\hline 2 & 7 & $80 \%$ & 2 & - & - \\
\hline 3 & - & - & 3 & - & - \\
\hline 4 & - & - & 4 & 1 & $10 \%$ \\
\hline 5 & - & - & 5 & - & - \\
\hline 6 & 1 & $10 \%$ & 6 & - & - \\
\hline 7 & 1 & $10 \%$ & 7 & - & - \\
\hline 8 & - & - & 8 & 3 & $40 \%$ \\
\hline 9 & - & - & 9 & 2 & $20 \%$ \\
\hline 10 & - & - & 10 & 3 & $30 \%$ \\
\hline Total & 9 & $100 \%$ & & 9 & $100 \%$ \\
\hline
\end{tabular}

From the table above, pupils woefully failed the pre-test given to them when the problem of reading difficulty was being identified. With this, nine (9) or eighty percent (80\%) pupils scored only two (2) marks. None of the pupils was able to score all the ten (10) marks.

One person or about ten percent (10\%) of the pupils scored one (1) mark which was not encouraging. So the researcher used a lot of intervention activities such as the use of flash cards, syllabic and phonic methods in order to overcome their reading problems and now they are really making it to the highest level.

After the intervention activities, there was a sudden change in the performance in the post-test given to them to see whether the methods used by the researcher have been very effective. Here are scores of the post-test. With this, three (3) or forty (40\%) of pupils scored ten (10) marks. Also another three (3) or thirty percent $(30 \%)$ of them also scored eight (8) marks.

Furthermore, another one (1) or ten (10\%) scored four (4) marks and an average student at that. He is actually improving.

\section{Conclusion}

Applying strategies such as the use of word and sentence cards, syllabic and phonic methods facilitated reading rather than plunging pupils in reading without the necessary preparatory work. An attempt was made 
to carry out an investigation into factors relating to the poor reading ability of the Abuakwa R/C Primary School (class 4) pupils in the East Akyem Municipal. The aims of the study were met because the post-test result revealed much improvement in the reading ability of the pupils.

\section{References}

[1.] Butler, D. (1982). Reading begins at home. Theory into Practice (no. 4: 308-314)

[2.] Fader, D. (1966). Hooked on books. Elmsford NY: Pergamon Press Fricke, S.C. (1977). Challenging the teenage reader. Crux. 11 no.3): 39-45.

[3.] Meek, M., Warlow, A. and Barton, G. (1979). The Cool Web -The Pattern of Children's Reading: This selection and critical commentary. Published London, England Bodley Head 1978.pp 428.

[4.] Mellon, C. A. (1990). Leisure reading choices of rural teens. Sxhool library Media Quarterly. 19 (no.4):223 228.

[5.] Ngendane, N. (1989). Parents' involvement in fostering reading habits. In National Libraries of Southern Africa: State Library. P.109-115

[6.] Stripling, B. (1985). "Teenagers and Reading: The Library Connection." Catholic Library World 56: $375-378$.

[7.] Thompson, B. (1979). Reading success: a guide for teachers and parents. London: Sidgwick \& Jackson.

[8.] Thorpe, D. (1988). Reading for fun: a study of how parents and libraries encouraged children aged 9-12 to read for enjoyment: The after school activities of 9-12 years old. Cranfield: Cranfield Press.

[9.] Zwarenstein, M. (1986). Motivating children to read. Canadian Library Journal. 43 (No. 06): $402-$ 406. 